\title{
Biodegradative activities of fungal isolates from plastic contaminated soils
}

\author{
El-Morsy EM ${ }^{1}$, Hassan $\mathrm{HM}^{2}$ and Ahmed $\mathrm{E}^{3,4^{*}}$ \\ ${ }^{1}$ Botany Department, Damietta University, Egypt \\ ${ }^{2}$ Toxicology and Microanalysis Unit, Suez Canal University, Egypt \\ ${ }^{3}$ Department of Geological Sciences, Stockholm University, Sweden \\ ${ }^{4}$ Science for Life Laboratory, Stockholm University, Sweden
}

El-Morsy EM, Hassan HM, Ahmed E 2017 - Biodegradative activities of fungal isolates from plastic contaminated soils. Mycosphere 8(8), 1071-1087, Doi 10.5943/mycosphere/8/8/13

\begin{abstract}
Fungal strains were isolated from plastic contaminated soils in open dump sites located in different governorates in Egypt. The isolates showed various abilities in enzymes production that were related to soil origins and characteristics. For example, fungi isolated from El-Sharqia soil were able to produce protease, esterase, lipase followed by those isolated from Ismailia soil. Moreover, isolates with high esterase activity were identified as Monascus ruber, Monascus sanguineus and Monascus sp. The results showed that $M$. ruber could produce maximum esterase concentration followed by $M$. sanguineus. The same three Monascus species were selected to assess polyurethane biodegradation. Monascus sp. isolated from El-Sharqia was the most efficient isolate in degradation of polyurethane in the form of Impranil DLN. In addition, SEM micrographs and zeta potential measurements confirmed the adsorption and complex formation between the polyurethane and the hyphae of Monascus sp.
\end{abstract}

Key words - Enzymes - Monascus - Polyurethane

\section{Introduction}

As the world's population continues to grow, so does the amount of plastic wastes that people produce. Plastic is composed of major toxic pollutants and thus it has the potential to negatively impact the natural environment and create severe problems for plants, wildlife and even human populations (Thompson et al. 2009, Halden 2010, North \& Halden 2013).

The accumulation of these products has led to increasing the amounts of plastic pollution around the world. Plastic wastes are commonly accumulated in soil due to the very slow rate of degradation. As a consequence, the toxic chemicals that are included in the plastic structure (i.e. bisphenol A and phthalates) are released in the soil and affect negatively both soil ecosystem and human health (Shah et al. 2008, Das \& Kumar 2014).

Egypt generated more than 20 million tons of municipal solid waste (MSW) in 2013 and plastic wastes (mostly polyurethane) were approximately $13 \%$ of the total MSW (Ali et al. 2014). There are three main mechanisms for plastic waste management in Egypt and worldwide; landfilling, recycling, and incineration (Al-Maaded et al. 2012, Mostafa 2016). However, those mechanisms produce toxic gases such as chlorofluorocarbon (CFC), vinyl monomers and dioxins (Jayasekara et al. 2005). According to the latest plastic waste estimation done by the Plastic Technology Center, $35 \%$ of the 
plastic waste in Egypt is recycled, 33\% is buried in open dump sites, and 32\% is burned (Mostafa 2016).

Recently, bioremediation of plastic waste was considered as an economic and environmentfriendly strategy for plastic waste management that could totally reduce the severe pollution produced from the conventional plastic remediation methods (Muenmee et al. 2016, Broszeit et al. 2016). Both fungi and bacteria have demonstrated their ability for plastic degradation by some studies which proved incorporation of microbial species in the degradation of both natural and synthetic plastics (Gu et al. 2000b, Shimao 2001, Tokiwa et al. 2009, Zafar et al. 2014, Lipsa et al. 2016). However, fungi could play a remarkable role in degradation of polymers in soil due to their high ability to produce variety of enzymes such as Glucosidase, Cutinase, amylase, lipase, esterase, cellulase, pectinase and hemicellulase (Kim \& Rhee 2003, Maeda \& Yamagata 2005, Anastasi et al. 2013).

A few previous studies have isolated fungi from plastic contaminated soils and investigated its ability in degrading plastic polymers (e.g. Zahra et al. 2010, Raaman et al. 2012, Sumathi et al. 2016, Indumathi \& Gayathri 2016). Zahra and colleagues (2010) found that the fungal isolates that were recovered from plastic contaminated landfill and were identified as Acremonium flavum, Candida rugosa, Arthrographis kalrae, Aspergillus sp., Lichtheimia sp., Aspergillus fumigatus, Emericella nidulans, Aspergillus terreus and Fusarium solanifrom had a high affinity in colonizing and degrading polyethylene. Moreover, Raaman et al. (2012) investigated the diversity of fungi in plastic contaminated soils and their efficiency in polyethylene degradation under laboratory conditions. Recently, two studies shed the light on the isolation and characterization of fungi from contaminated soils. One study isolated fungal strains from open dump site contaminated with plastic and screened them for laccase production, which is an essential enzyme for biodegradation of polymers (Sumathi et al. 2016). On the other hand, Indumathi and Gayathri (2016) isolated fungal strains from plastic contaminated soil and investigated their abilities in plastic degradation in situ.

Thus, due to the vital role of fungi in biodegradation of polymers in soil, the main aim of the present study is to a) investigate the ability of fungal isolates recovered from different plastic contaminated soils in open dump sites in Egypt to produce different plastic-degrading enzymes in an attempt to gain a better understanding whether soil origin and characteristics could affect the degradation activity of fungi, and b) explore the capability of the most efficient enzyme producing fungal isolates in polyurethane degradation under laboratory conditions.

\section{Materials \& Methods}

\section{Sampling sites and physico-chemical characterization of soils}

Soil samples were collected from plastic contaminated open dump sites located in different governorates (Ismailia, Portsaid, EL-Sharqia, Damietta and Saint Katherine) in Egypt (Fig. 1). Five sub-samples were taken from each site from the top $10 \mathrm{~cm}$ of the soil profile using a sterile spatula. Then the soil samples were kept cold $\left(+4^{\circ} \mathrm{C}\right)$ until further analysis.

The physico-chemical characteristics of soil samples were determined. The determination of organic content in soil samples was done using loss-on-ignition (LOI) method. One gram of each soil sample was first dried at $105^{\circ} \mathrm{C}$ overnight. Samples were weighed after dryness and then were heated at $550^{\circ} \mathrm{C}$ in a muffle. The samples were weighed again after cooling them in a desiccator. Organic matter content was calculated according to the following equation (Heiri et al. 2001): $\mathrm{W}_{2}-\mathrm{W}_{1} /$ $\mathrm{W}_{1} * 100\left\{\mathrm{~W}_{1}\right.$ (dry weight before ignition); $\mathrm{W}_{2}$ (weight after ignition) $\}$.

In order to measure the concentration of heavy metals, $1 \mathrm{~g}$ of soil sample was ashed in a muffle at $500^{\circ} \mathrm{C}$ and then was digested in $10 \mathrm{ml}$ of $\mathrm{HNO}_{3}$. Elements such as $\mathrm{Fe}, \mathrm{Zn}, \mathrm{Co}, \mathrm{Ni}, \mathrm{Cu}$ and $\mathrm{Mn}$ were measured using atomic absorption spectroscopy (AAS) (Thermo electron corp, S-series, USA). The $\mathrm{pH}$ values of the soil extracts were measured by $\mathrm{pH}$ meter (UB10, Denver, USA) (Maiti 2003). Electrical conductivity (EC) was determined in soil extracts using electrical conductivity meter (SensoDirect Con 200, lovibond, UK) (Maiti 2003). 


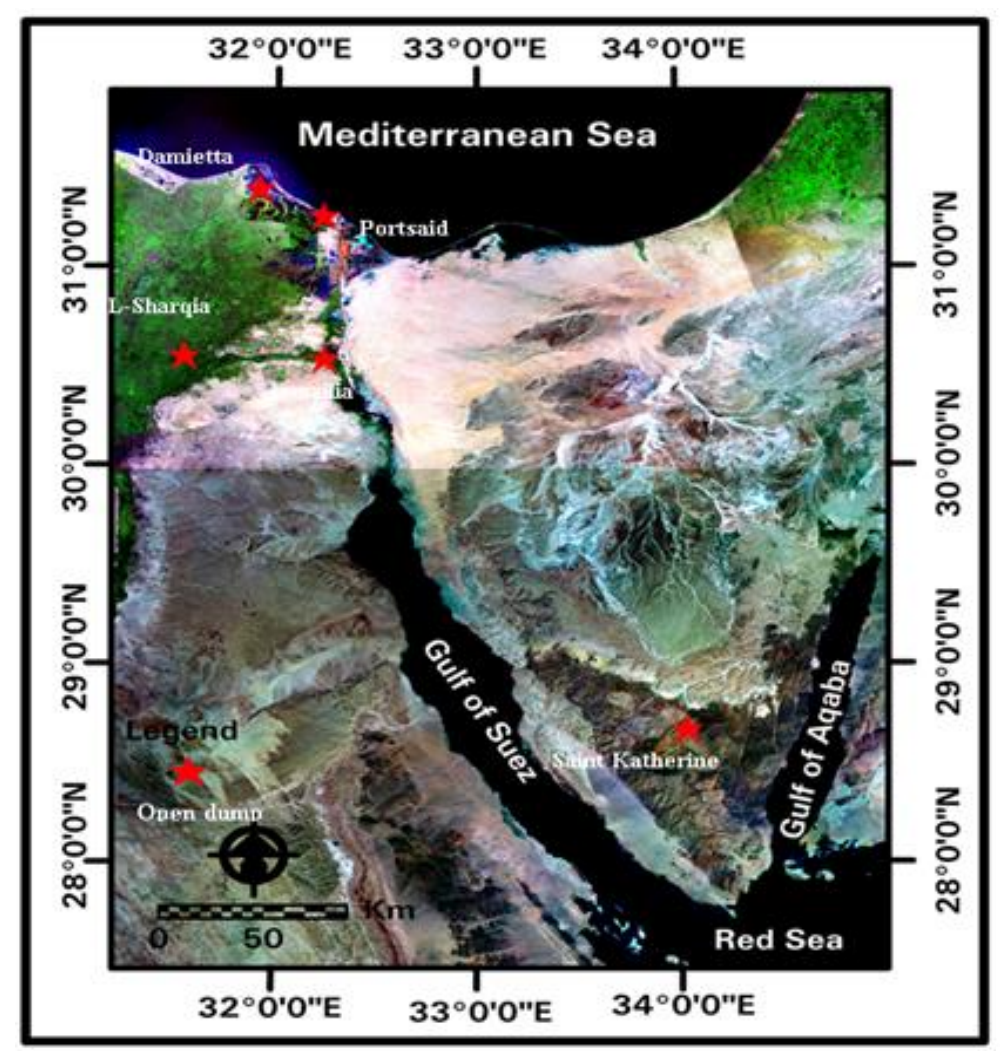

Figure 1 - Map of the sampling sites located in different governorates (Ismailia, Portsaid, ELSharqia, Damietta and Saint Katherine) in Egypt.

\section{Isolation of polymer-degrading fungi from soil}

Polymer-degrading fungi were isolated from all the soil samples solution. Soil extracts were obtained by shaking $10 \mathrm{~g}$ of soil in $90 \mathrm{ml}$ of sterilized MilliQ water for 1 hour and then centrifuged for $15 \mathrm{~min}$ at $5000 \mathrm{rpm}$. Then the supernatants were serially diluted. The $1 \mathrm{ml}$ of the $1 / 100$ dilution of the soil solution were plated using the pour plate technique onto five replicates of minimal media containing polyurethane diol or poly vinyl chloride in order to be selective for the isolation of polymer-degrading fungi. Fungi were isolated using minimal medium containing (grams per liter of distilled water) $\mathrm{K}_{2} \mathrm{HPO}_{4}, 0.5 ; \mathrm{KH}_{2} \mathrm{PO}_{4}, 0.04 ; \mathrm{NaCl}, 0.1 ; \mathrm{CaCl}_{2} . \mathrm{H}_{2} \mathrm{O}, 0.002 ;\left(\mathrm{NH}_{4}\right)_{2} \mathrm{SO}_{4}, 0.2$; $\mathrm{MgSO}_{4} .7 \mathrm{H}_{2} \mathrm{O}, 0.02 ; \mathrm{FeSO}_{4}, 0.001$, agar 20.0, supplemented separately with two different polymers as the only carbon sources: $1.0 \%$ polyurethane-diol (PUR-diol) or $1.0 \%$ poly vinyl chloride (PVC). The $\mathrm{pH}$ of the medium was 7.2 . The inoculated plates were incubated at $28^{\circ} \mathrm{C}$ for $7-14$ days. The polymer-degrading fungal isolates were preserved at $4^{\circ} \mathrm{C}$ in $2 \%$ agar slants of potato dextrose medium (PDA) (gram per liter): potato infusion, $200 \mathrm{~g}$; dextrose, $20 \mathrm{~g}$; agar, $15 \mathrm{~g}$.

\section{Screening for enzymes production by isolated polymer-degrading fungi}

\section{Lipase production}

In order to screen the ability of the isolated fungi for lipase production, the isolates were inoculated in SIERRA medium plates (peptone, $10.0 \mathrm{~g} ; \mathrm{NaCl}, 5.0 \mathrm{~g} ; \mathrm{CaCl}_{2} . \mathrm{H}_{2} \mathrm{O}, 0.1 \mathrm{~g}$; distilled water, $1000 \mathrm{ml}$ ) using sterilized cork-borer to cut $5 \mathrm{~mm}$ blocks from cultured fungal mycelia. The medium was supplemented with $1 \%$ of separately autoclaved tween 80 . The plates were incubated at $28^{\circ} \mathrm{C}$ for 5 days. Lipase production by the isolates was indicated by the formation of opaque haloes around the cultures as a result of precipitation of insoluble calcium salt released by lipolysis (Sierra 1956, Bakir $\&$ Metin 2015). In the evaluation of the result, the detection of the different lipase production capabilities was calculated according to relative enzyme activity (RA) (Bradner et al. 1999, Duncan et al. 2008):

$\mathrm{RA}=$ clear zone diameter - colony diameter / clear zone diameter 


\section{Esterase production}

Esterase-producing fungi were assessed by their ability to hydrolyze Tween 20 . The isolates were inoculated in basal medium contains $10 \mathrm{~g}$ of peptone, $1 \mathrm{~g}$ of yeast extract, $0.05 \mathrm{~g}$ of $\mathrm{CaCl}_{2}, 15$ $\mathrm{g}$ of agar using sterilized cork-borer to cut $5 \mathrm{~mm}$ blocks from cultured fungal mycelia. The medium was supplemented with $1 \%$ Tween 20 . The plates were incubated at $28^{\circ} \mathrm{C}$ for 5 days. Esterase production by the isolates was indicated by the formation of white haloes around the cultures as a result of precipitation of calcium salt (Castro et al. 1992, Hosoya et al. 2009). The detection of the different esterase production capabilities was calculated according to relative enzyme activity (RA) as described above.

\section{Laccase production}

Laccase enzyme production by fungal isolates was detected by inoculating them in PDA plates (Potato Infusion, $200 \mathrm{~g}$; Dextrose, $20 \mathrm{~g}$; agar, $15 \mathrm{~g}$ ) supplemented with $4 \mathrm{mM}$ guaiacol. The plates were incubated at $30^{\circ} \mathrm{C}$ for 5 days. Laccase production by the isolates was indicated by the formation of reddish-brown haloes around the cultures as a result of oxidation of guaiacol (Gnanasalomi \& Gnanadoss 2013). The detection of the different laccase production capabilities was calculated according to relative enzyme activity (RA) as described above.

\section{Protease production}

In order to assess protease production by fungi, the isolates were inoculated in media composed $20 \mathrm{~g}$ sucrose, $5 \mathrm{~g}$ yeast extract, $20 \mathrm{~g} \mathrm{KCl}$ and $15 \mathrm{~g}$ agar, supplemented with $10 \mathrm{~g}$ gelatin. The plates were incubated at $28^{\circ} \mathrm{C}$ for 10 days. The detection of protease production was done by staining the medium with $0.25 \%$ coomassie blue (diluted in methanol: acetic acid: water (5:1:4)). Protease production by the isolates was indicated by the formation of transparent haloes around the cultures as a result of hydrolysis of the substrate (Vermelho et al. 1996). The detection of the different protease production capabilities was calculated according to relative enzyme activity (RA) as described above.

\section{Polyurethanase production}

Fungal isolates were assessed for their ability to degrade polyurethane (PUR) using modified method from Russel et al. (2011), by inoculating them in solid PUR medium containing (grams per liter of distilled water) $\mathrm{K}_{2} \mathrm{HPO}_{4}, 0.5 ; \mathrm{KH}_{2} \mathrm{PO}_{4}, 0.04 ; \mathrm{NaCl}, 0.1 ; \mathrm{CaCl}_{2} . \mathrm{H}_{2} \mathrm{O}, 0.002 ;\left(\mathrm{NH}_{4}\right)_{2} \mathrm{SO}_{4}, 0.2$; $\mathrm{MgSO}_{4} .7 \mathrm{H}_{2} \mathrm{O}, 0.02 ; \mathrm{FeSO}_{4}, 0.001$, Agar 20.0. The medium was supplemented with $10 \mathrm{ml}$ impranil DLN (Anionic aliphatic polyester-polyurethane dispersion (Bayer Material Science, Germany)). Polyurethanase production by the isolates was indicated by the formation of transparent haloes around the cultures. The detection of the different polyurethanase production capabilities was calculated according to relative enzyme activity (RA) as described above.

\section{Identification of fungal isolates}

The most efficient fungal isolates in esterase enzyme production were identified genetically. The isolated fungi were individually inoculated into $100 \mathrm{ml}$ of potato dextrose broth medium and were incubated on a rotary shaker $(120 \mathrm{rpm})$ for 1-3 days. The biomass was harvested by centrifugation at $3000 \mathrm{rpm}$ for $10 \mathrm{~min}$, then washed twice with sterilized deionized water and again centrifuged at $3000 \mathrm{rpm}$ for $10 \mathrm{~min}$ to collect the fungal cells. The fungal genomic DNA was extracted by using Blood-Animal-Plant DNA Kit (Jena Bioscience, Germany) according to the manufacturer's instructions. The quantity of DNA was measured using a NanoDrop spectrophotometer (ND-1000, Thermo Fisher Scientific, USA) at $260 \mathrm{~nm}$. The molecular identification was carried out by amplification of a set of universal primers. ITS1f (5'TCCGTAGGTGAACCTGCGG-3') and ITS4 (5'- TCCTCCGCTTATTGATATGC-3') primers were used. The PCR reaction was performed by adding $1 \mu 1$ of template DNA in $50 \mu 1$ of PCR reaction solution (10X MGTM Taq-HF buffer $10 \mu \mathrm{l}$; $2 \mathrm{mM}$ MGTM dNTP mixture $10 \mu \mathrm{l}$; 10 pmol Primer 5 $\mu \mathrm{l}$; MGTM Taq-HF polymerase $1 \mu \mathrm{l}$; Distilled water). The thermal cycling conditions were as follows: initial denaturing step of $95^{\circ} \mathrm{C}$ for $3 \mathrm{~min}$, followed by 35 amplification cycles of $95^{\circ} \mathrm{C}$ for 
$30 \mathrm{~s}, 50^{\circ} \mathrm{C}$ for $45 \mathrm{~s}$, and $72^{\circ} \mathrm{C}$ for $90 \mathrm{~s}$ and a final extension step of $72^{\circ} \mathrm{C}$ for $10 \mathrm{~min}$. PCR amplification products were electrophoretically separated on $1.0 \%(\mathrm{w} / \mathrm{v})$ agarose gels. The DNA sequencing was done by the sequencing service Macrogen inc. (http://www.macrogen.com). The obtained sequences were compared to sequences in the NCBI GenBank database using the BlastN (Altschul et al. 1990). All the sequences were submitted to the GeneBank under accession numbers (KX495607; KX495608; KX495609).

\section{Measurement of esterase activity}

Esterase plays a major role in biodegradation of plastic in particular polyurethane (Christenson et al. 2006). The most efficient isolates in producing esterase in the plate assay (described above) were chosen for esterase quantification using spectrophotometric method (Kordel et al. 1991). Isolates were inoculated in potato dextrose broth medium on orbital shaker at $120 \mathrm{rpm}$ in $28^{\circ} \mathrm{C}$. The 2-3 ml of medium was collected in intervals (3, 5, 7, 9 and 12 days) and was centrifuged at $3000 \mathrm{rpm}$ for 5 minutes. Esterase was determined in the supernatant after removal of fungal mycelium. The reaction mixture consisted of p-nitrophenyl acetate $(16.5 \mathrm{mM})$ dissolved in 2-propanol $(0.5 \mathrm{mM})$ and then mixed with $50 \mathrm{mM}$ Tris- $\mathrm{HCl}$ buffer ( $\mathrm{pH}$ 8.0). The medium was supplemented with triton $\mathrm{X}-100$ $(0.4 \%)$ and gum Arabic $(0.1 \%)$. The $0.15 \mathrm{ml}$ of cell-free supernatant was added to $1.35 \mathrm{ml}$ of the reaction mixture and the esterase activity was determined by UV/VIS spectrophotometer (T90, PG instruments, $\mathrm{UK}$ ) at $\mathrm{OD}_{405}$. The esterase activity was quantified according to the rate of p-nitophenyl acetate hydrolysis, in which one unit of enzyme activity was defined as $1 \mu \mathrm{mol}$ of p-nitrophenol per minute (Kordel et al. 1991).

\section{Polyurethane biodegradation}

The three fungal isolates that were chosen for esterase activity measurement were also tested for their ability to degrade and utilize polyurethane (PUR) as the sole carbon source. The substrate used in this study was Impranil DLN, which contains PUR suspended in only water (Russell et al. 2011). Fungal cultures were grown for 2-3 days in potato dextrose broth (PDB). One ml of each culture was centrifuged at $3000 \mathrm{rpm}$ for 5 minutes. The supernatant was removed, and the fungal pellets were washed three times with sterile distilled water to ensure that there was no other carbon source prior to inoculation in liquid medium supplemented with Impranil DLN. The $1 \mathrm{ml}$ sample of washed fungal pellets was inoculated to sterile flasks to a final volume of $50 \mathrm{ml}$ of $1 \%(\mathrm{v} / \mathrm{v})$ Impranil DLN on orbital shaker at $120 \mathrm{rpm}$ in $28^{\circ} \mathrm{C}$. The cultures were monitored for visual clearance of the opaque medium. Samples were measured in intervals, after 2, 4, 6, 8, 10, 12, 14 days for optical absorbance at $600 \mathrm{~nm}$ to determine an approximate rate of clearance. Inoculated minimal medium without PUR was used as a control.

\section{Scanning electron microscopy}

Scanning electron microscopy was used to show the adsorption of polyurethane on the hyphae of the most efficient degrading fungal isolate. Specimens from the fungal culture were collected from the liquid medium with and without (used as a control) PUR at the end of the biodegradation experiment (after 14 days). The fungal cultures were fixed and dehydrated prior to SEM analysis using a method modified from Echlin (2009). For fixation, the fungal cultures were incubated in 2.5 $\%$ glutaraldehyde (diluted in $0.1 \mathrm{M}$ phosphate buffer, $\mathrm{pH}$ 7.4) for 20-40 minutes. Then, the samples were rinsed in $0.1 \mathrm{M}$ phosphate buffer ( $\mathrm{pH}$ 7.4) twice for 5 minutes. For washing, the samples were rinsed in distilled water twice for $1 \mathrm{~min}$. Fungal cultures were dehydrated in a series of ethanol (70, $90 \%$ for $10 \mathrm{~min}$ and $100 \%$ for $15 \mathrm{~min}$ ). Final desiccation was accomplished by critical point drying. Fungal cultures were mounted on aluminum stubs and sputter-coated with gold for 3 minutes. All the samples were then observed by SEM (JEOL JSM-6510L, Japan).

\section{Zeta potential measurement}


In order to examine the formation of a complex between fungi and polyurethane, zeta potential of the most efficient degrading fungal isolate was determined. The determination was done at the end of the biodegradation experiment (after 14 days). In addition, zeta potential was measured in inoculated minimal medium without PUR as a positive control and un-inoculated minimal medium with PUR as a negative control. Zeta potential was measured using the Zeta PALS instrument (Malvern Zetasize, Nano-zs90, UK).

\section{Data analysis and statistics}

The data were normalized and one/two-way ANOVA were analyzed by using XLSTAT (http://www.xlstat.com/en/).

\section{Results}

\section{Soil physical and chemical characteristics}

In general, soil samples collected from different locations varied in most of the characteristics (Table 1). Organic carbon content of the soil samples was ranged between 2.21 and $7.75 \%$, in which both EL-Sharqia and Portsaid had the maximum concentration $(7.75 \%)$ and Saint Katherine had the minimum concentration (2.21\%). The electrical conductivity (EC) of the soils was ranged between 3.29 and $136.08 \mathrm{mS} / \mathrm{cm}$. The soil collected from Portsaid had the highest EC value $136.08 \mathrm{mS} / \mathrm{cm}$ while the minimum EC value $3.29 \mathrm{mS} / \mathrm{cm}$ was found in Saint Katherine The concentration of heavy metals was found in the following configuration $\mathrm{Fe}>\mathrm{Zn}>\mathrm{Mn}>\mathrm{Cu}>\mathrm{Ni}$ in almost all the soils collected from different location. However, EL-Sharqia soil was characterized by the maximum concentration of Fe $(6128 \mathrm{mg} / \mathrm{kg})$ and $\mathrm{Zn}(760.9 \mathrm{mg} / \mathrm{kg})$. On the other hand, the $\mathrm{pH}$ value of soil samples was ranged between 7.75 and 8.3 , and no obvious difference with regards to the location.

Table 1 Chemical and physical characteristics of soil samples from Ismailia, Portsaid, EL-Sharqia, Damietta and Saint Katherine. The average content of metals $(\mathrm{mg} / \mathrm{kg})$ was determined. Organic content $(\%), \mathrm{pH}$ and electrical conductivity $(\mathrm{EC})(\mathrm{mS} / \mathrm{cm})$ were also estimated.

\begin{tabular}{lcccccccc}
\hline Sample site & $\begin{array}{c}\mathbf{N i} \\
(\mathbf{m g} / \mathbf{k g})\end{array}$ & $\begin{array}{c}\mathbf{M n} \\
(\mathbf{m g} / \mathbf{k g})\end{array}$ & $\begin{array}{c}\mathbf{Z n} \\
(\mathbf{m g} / \mathbf{k g})\end{array}$ & $\begin{array}{c}\mathbf{C u} \\
(\mathbf{m g} / \mathbf{k g})\end{array}$ & $\begin{array}{c}\mathbf{F e} \\
(\mathbf{m g} / \mathbf{k g})\end{array}$ & $\mathbf{E c}(\mathbf{m S} / \mathbf{c m})$ & $\mathbf{p H}$ & $\begin{array}{c}\text { Organic } \\
\text { content }\end{array}$ \\
\hline \multirow{2}{*}{ Ismailia } & 2.88 & 52.35 & 107.49 & 27.385 & 1557.45 & 11.7125 & 7.75 & $5.3 \%$ \\
& \pm 2.06 & \pm 10.4 & \pm 47.23 & \pm 11.64 & \pm 25.53 & \pm 1.38 & \pm 0.21 & \pm 0.0007 \\
Portsaid & 6.32 & 162.52 & 492.7 & 312.2205 & 3701.6 & 136.08 & 7.85 & $7.75 \%$ \\
& \pm 1.82 & \pm 19.88 & \pm 90.65 & \pm 272.32 & \pm 1303.34 & \pm 13.32 & \pm 0.35 & \pm 0.016 \\
EL-Sharqia & 9.49 & 139.465 & 760.9 & 102.635 & 6128 & 36.233 & 8.25 & $7.75 \%$ \\
& \pm 0.96 & \pm 16.37 & \pm 262.62 & \pm 28.18 & \pm 926.02 & \pm 2.78 & \pm 0.07 & \pm 0.0009 \\
Damietta & 8.425 & 177.485 & 110.275 & 26.26 & 3805.6 & 49.76 & 7.75 & $5.63 \%$ \\
& \pm 3.62 & \pm 0.6 & \pm 31.81 & \pm 23.36 & \pm 973.83 & \pm 1.78 & \pm 0.35 & \pm 0.010 \\
Saint Katherine & 3.285 & 101.73 & 32.88 & & 1642.1 & 3.29 & 8.3 & $2.21 \%$ \\
& \pm 1.8 & \pm 16.4 & \pm 5.99 & 0 & \pm 4.1 & \pm 0.19 & \pm 0.14 & \pm 0.005 \\
\hline
\end{tabular}

\section{Enzyme production by polymer-degrading fungi}

The 33 fungal isolates recovered from the different sampling sites varied completely in their abilities to produce enzymes (Fig. 2). In general, our findings revealed that $66.7 \%$ of the total number of isolates was protease and esterase producers (Fig. 2). Lipase was produced by $72.7 \%$ of the total number of isolates, whereas only two isolates (PL 27) and (PL 28) had the ability to produce laccase and polyurethanase enzymes, respectively .

There was a correlation between enzyme production by fungal isolates and the sampling sites where they were isolated (Fig. 2). The results revealed that $63 \%$ of the fungal isolates from El-Sharqia could produce high amount of protease, esterase and lipase, followed by the $50 \%$ of the isolates from Ismailia and $100 \%$ from Damietta produced the same enzymes but in much lower amount. The 
isolates from Portsaid had low abilities in enzymes production, in which $70 \%$ of fungal isolates were capable to produce low amount of esterase and lipase only.

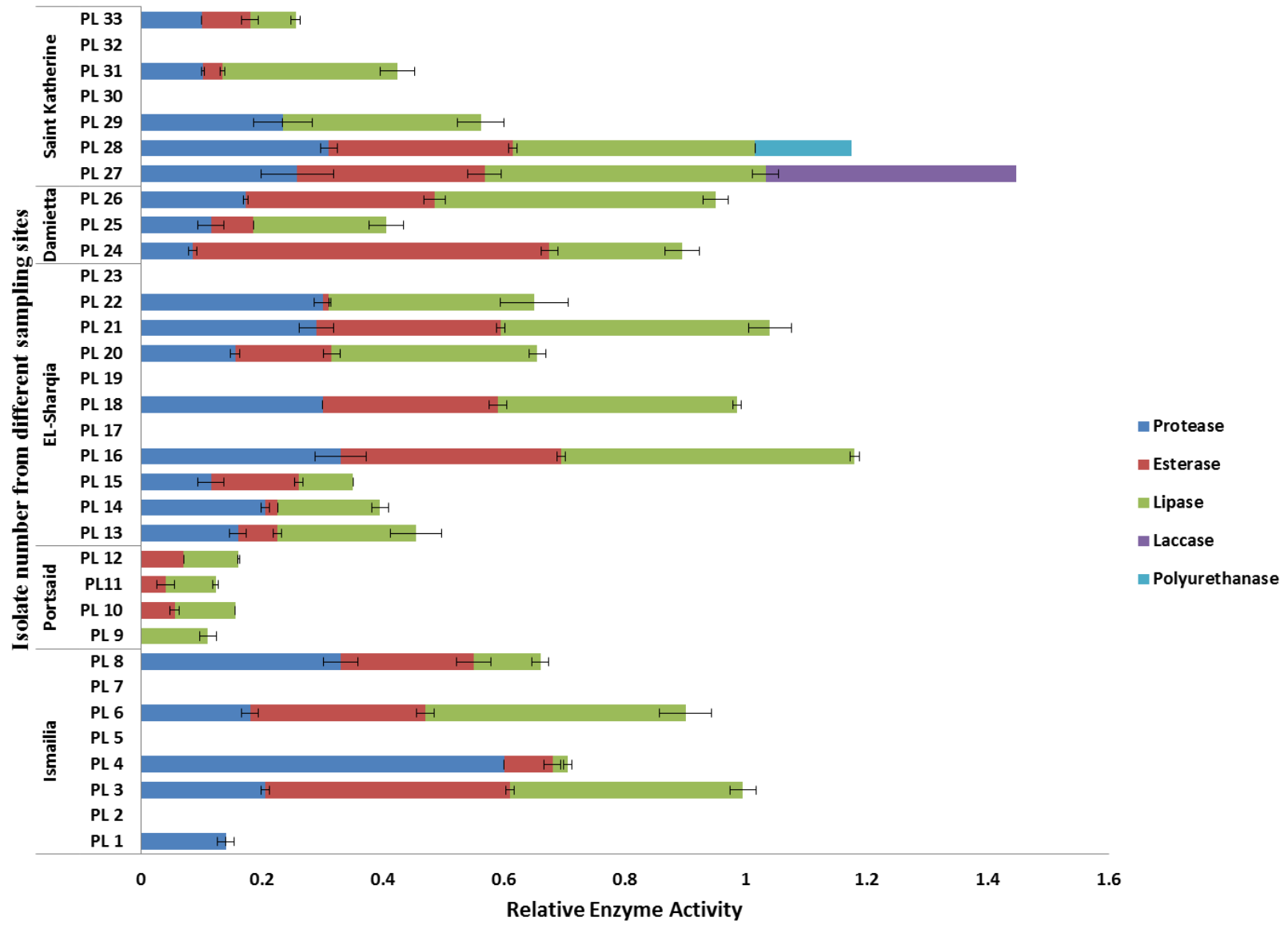

Figure 2 - Production of polymer degrading enzymes (protease, esterase, lipase, laccase and polyurethanase) by fungal isolates from plastic contaminated soils located in Ismailia, Portsaid, ELSharqia, Damietta and Saint Katherine.

\section{Quantification of esterase activity}

Esterase activity was measured in the culture filtrate of the most efficient isolates in producing esterase enzyme in the plate assay. Those isolates were identified genetically by comparing the obtained sequences to sequences in the NCBI GenBank to be M. ruber (PL 3), M. sanguineus (PL 24) and Monascus sp. (PL 16).

Our findings revealed that there is a significant difference ( $\mathrm{p}$-value $<0.05)$ between esterase production abilities by Monascus spp. isolated from different locations (Fig. 3). Maximum esterase concentration $\left(2.01 \mathrm{Uml}^{-1}\right)$ was produced by $M$. ruber that was isolated from Ismailia followed by M. sanguineus from Damietta $\left(1.96 \mathrm{Uml}^{-1}\right)$ and Monascus sp. from EL-Sharqia (1.35 $\left.\mathrm{Uml}^{-1}\right)$.

On the other hand, there was a significant difference (p-value < 0.05) between esterase production abilities by Monascus spp. with incubation time (Fig. 3). It was noticed that the rate of esterase activity increased with time for all the isolates except for $M$. sanguineus that showed a relatively similar concentration $\left(1.2 \mathrm{Uml}^{-1}\right)$ of esterase at both 3 and 5 days and then a gradual increasing in concentration was observed until reached the maximum concentration $\left(1.96 \mathrm{Uml}^{-1}\right)$ at 12 days. Moreover, the concentration of esterase produced by Monascus sp. was gradually increased by time until 9 days (Fig. 3). 


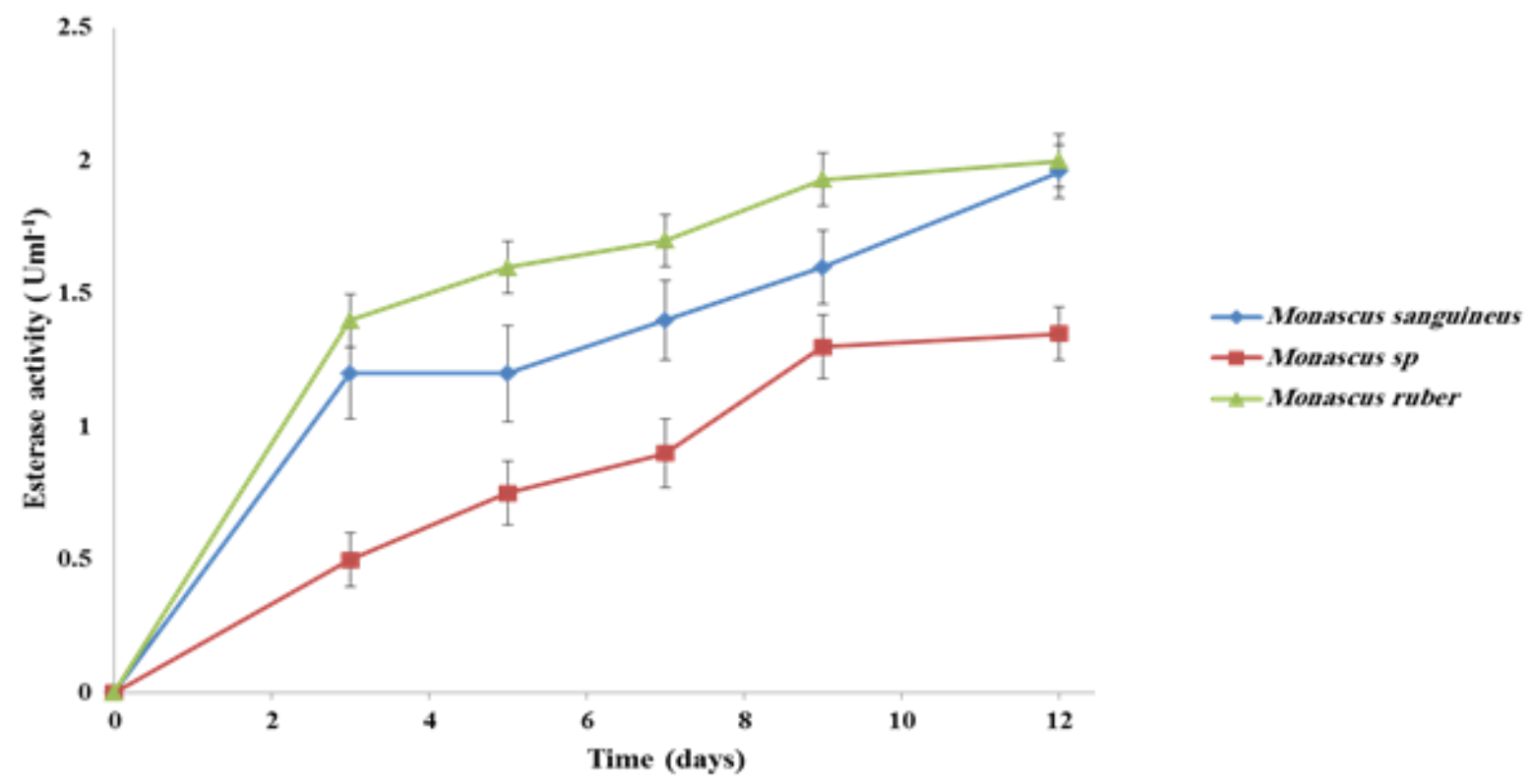

Figure 3 - Esterase activity $\left(\mathrm{Uml}^{-1}\right)$ of Monascus species isolated from different sampling sites.

\section{Degradation of polyurethane by fungal isolates}

The three most efficient isolates (M. ruber, M. sanguineus and Monascus sp.) in esterase production were tested for their capability to degrade PUR (Impranil DLN) in liquid medium. In order to compare the rates at which PUR was degraded, fungal isolates were grown in duplicate in minimal medium supplemented with Impranil DLN and tracked in intervals for 14 days (Fig. 4). The three fungal isolates showed the same rate of PUR clearance until 10 days. At day 12, Monascus sp. showed a higher clearness for Impranil DLN than M. ruber and M. sanguineus. The Impranil DLN inoculated with Monascus sp. was nearly transparent by the end of the experiment (after 14 days) in comparison with the control which characterized by its opaque milky color (Fig. 4).

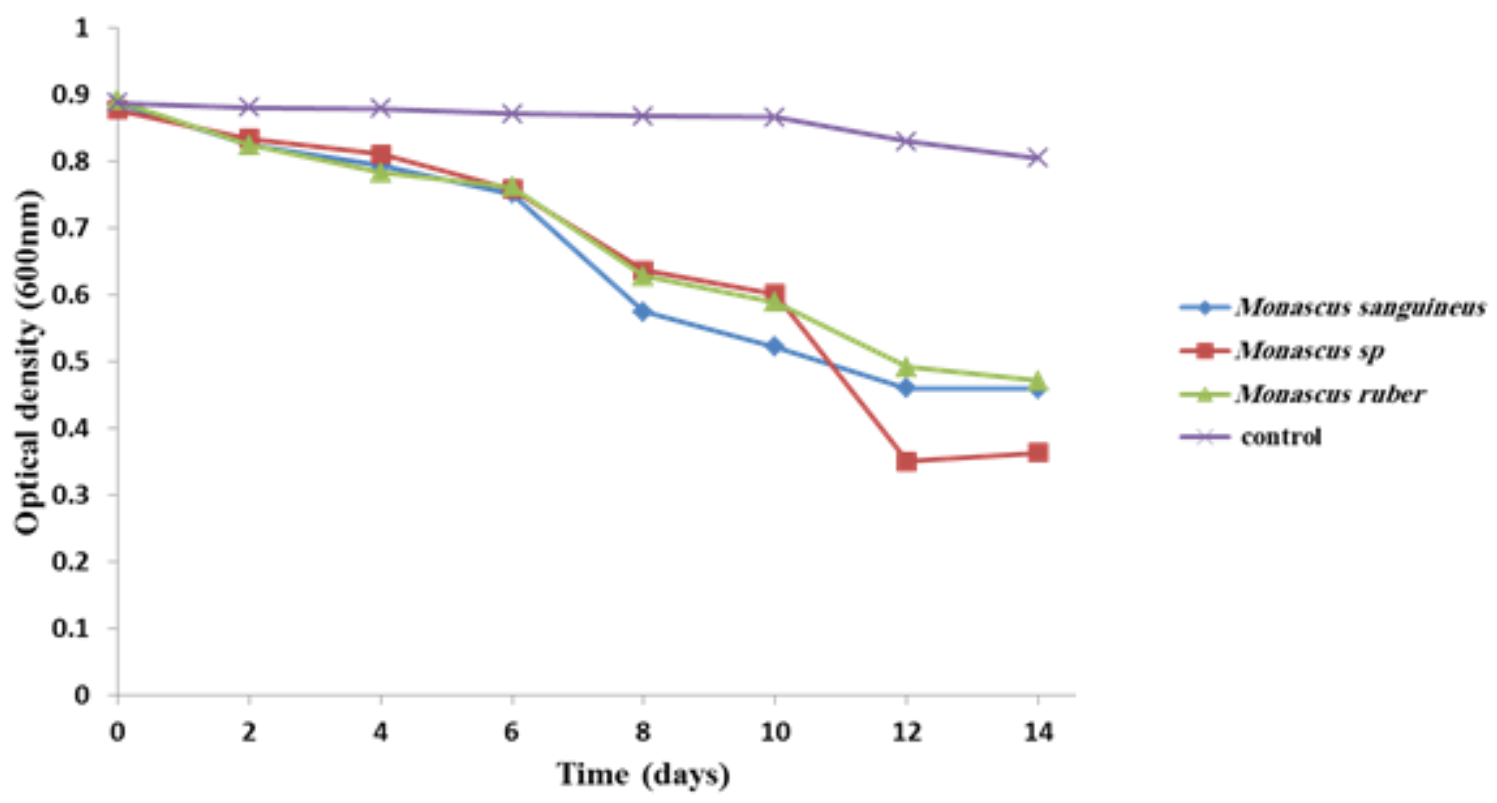

Figure 4 - Polyurethane degradation by M. ruber, M. sanguineus and Monascus sp. Samples were measured in intervals up to 14 days. Inoculated minimal medium without polyurethane was used as a control.

Scanning imaging of the most efficient degrading fungal isolate Monascus $\mathrm{sp}$. was done for the cultures inoculated in both Impranil DLN containing medium and control (Fig. 5). The hyphae of 
Monascus sp. recovered after 14 days of incubation in Impranil DLN containing medium were covered with massive aggregation of Impranil DLN particles (Fig. 5B). However, smooth hyphae were observed for Monascus sp. recovered after 14 days of incubation in control medium (Fig. 5A).
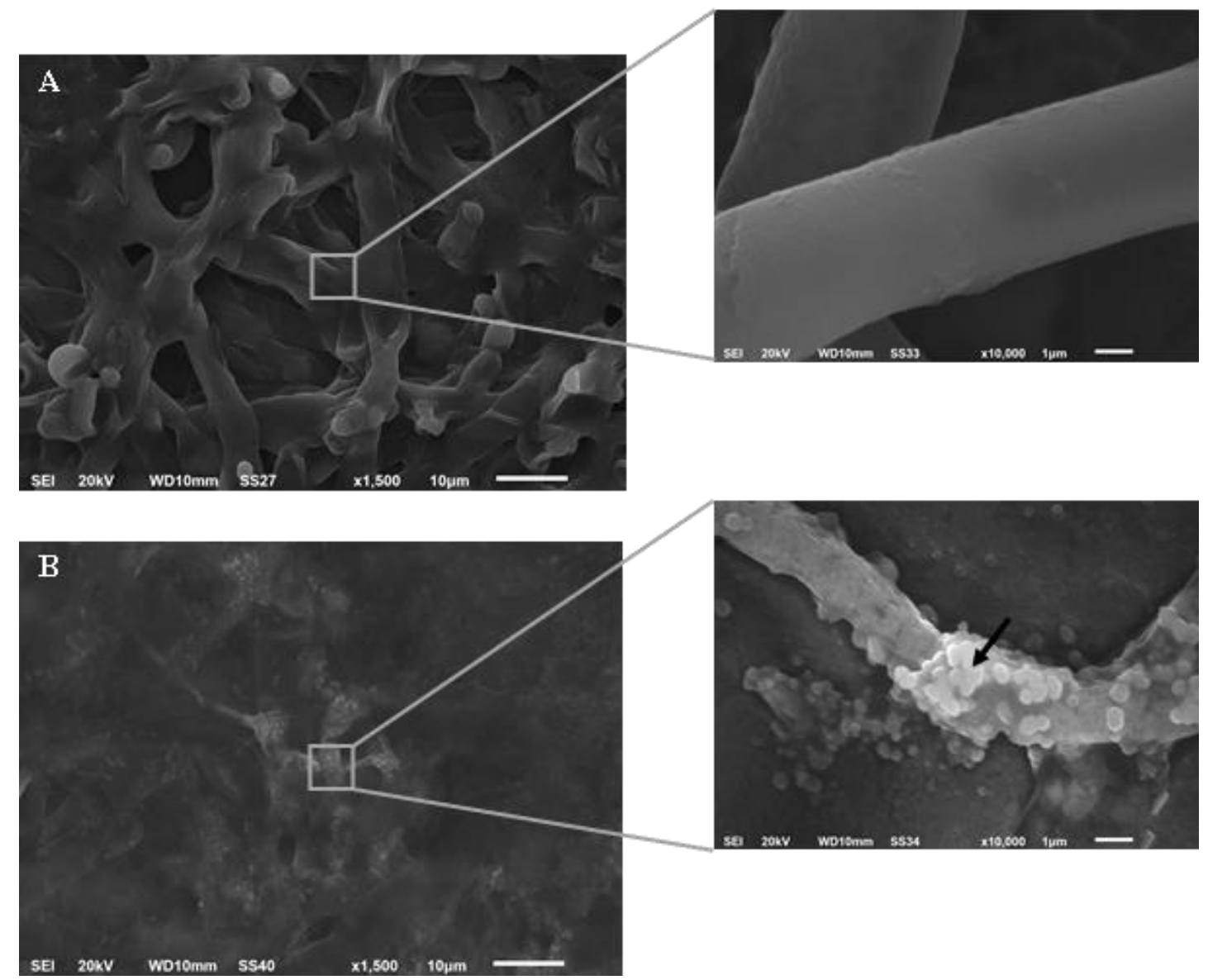

Figure 5 - SEM micrographs for Monascus sp. incubated in liquid medium (A) without (used as a control) and (B) with polyurethane after 14 days of the biodegradation experiment.

As scanning electron micrographs showed the adhesion of Impranil DLN particles on Monascus sp. hyphae, the electrophoretic mobility was determined in the form of zeta potential in order to confirm the formation of the complex. Our findings revealed that Impranil DLN had a strongly negative charge $-50.1 \pm 7.46 \mathrm{mV}$ (Table 2 ). However, the complex that was formed between Impranil DLN and Monascus sp. hyphae led to increasing in zeta potential $(-28.1 \pm 4.75 \mathrm{mV})$ when compared to the net charge $(-23.2 \pm 7.14 \mathrm{mV})$ of Monascus sp. hyphae in control medium (without Impranil DLN) (Table 2).

Table 2 Zeta potential measurements of complex formation between Monascus sp. hyphae and Impranil. Un-inoculated Impranil containing medium represented -ve control. Inoculated medium without Impranil represented +ve control.

\begin{tabular}{lc}
\hline Sample & Zeta potential $(\mathbf{m V})$ \\
\hline -ve control & $-50.1 \pm 7.46$ \\
+ve control & $-23.2 \pm 7.14$ \\
Monascus sp. with Impranil DLN & $-28.1 \pm 4.75$ \\
\hline
\end{tabular}

\section{Discussion}


Enzymes play an important role in polymer degradation in environment (Banerjee et al. 2016). Microorganisms are well known of its capability of polymer degradation using extracellular and intracellular degrading enzymes (Doi 1990, Gu et al. 2000a, Gu et al. 2000b). Polymer degradation by enzymes occurs by binding enzymes to polymer that catalyzes the hydrolytic cleavage (Shah et al. 2008). It is important to highlight that fungi produce different types of enzymes depending on the polymer substrate, thus we concerned screening the enzymes that could degrade polyurethane such as protease and esterase, lipase, laccase and polyurethanase as reported by Ibrahim et al. (2011). In the present study, 33 polymer degrading fungal isolates were recovered from highly contaminated soils with plastic wastes from different locations in Egypt. The fungal isolates varied widely in their ability in enzymes production, $66.7 \%$ of the total number of isolates produced protease and esterase, $72.7 \%$ produced lipase, whereas only two isolates produced laccase and polyurethanase. Earlier studies have also investigated enzymes production by polymer degrading fungi. Loredo-Treviño \& colleagues (2011) isolated polymer degrading fungi from plastic contaminated soil and found that the majority of the isolates $(95.45 \%)$ produced urease, $86.36 \%$ produced protease, $50 \%$ produced esterase, and $36.26 \%$ produced laccase. That was in line with other study by Bhardwaj et al. (2012) that showed that most of the polymer degrading fungal isolates was active producers for esterase, lipase, protease and urease enzymes which could degrade the polyurethane substrate by cleaving the ester bonds.

Soil physical and chemical characteristics such as pH (Stursova \& Sinsabaugh 2008), organic matter content (Allison \& Vitousek 2004, Sinsabaugh et al. 2008) and heavy metal (Wahsha et al. 2017) have been shown to be principal factors affecting both microbial community composition and their enzyme activities. Consequently, microbial enzyme activities will also vary in relation to the spatial distribution of soil properties across environments (Allison 2005). The impact of organic matter content on microbial enzymes activity has been studied previously (Bowles et al. 2014, Malý et al. 2014, Zhang et al. 2016, Wahsha et al. 2017). For instance, Wahsha et al. (2017) demonstrated that high organic matter content was positively correlated to high soil microbial biomass and as a consequence high soil enzyme activities for the investigated enzymes (arylsulfatase, leucyl aminopeptidase, $\beta$-glucosidase, alkaline phosphatase and chitinase). On the other hand, previous studies revealed that $\mathrm{pH}$ had a major impact on soil microbial community composition and enzyme activities in different soils (e.g. forest and grassland) (Lauber et al. 2009, Nicol et al. 2008, Stursova \& Sinsabaugh 2008). Sinsabaugh et al. (2008) studied the impact of soil acidic and alkaline pH on enzyme activities and their findings showed that $\mathrm{pH}$ was one of the major factors affect microbial enzyme activities. Moreover, the correlation between soil $\mathrm{pH}$ and activity of four enzyme types (cellulolytic, ligninolytic, organic $\mathrm{N}$-degrading and organic $\mathrm{P}$ degrading) was investigated and weak correlation was found when $\mathrm{pH}$ was in the range between 4.01 and 4.79 (Banerjee et al. 2016). Heavy metals affect strongly enzymes activities in soil (Huang \& Shindo 2000, Khan et al. 2007). Heavy metals are cofactors for many enzymes, thus it could stimulate enzymes activities of soil microbes (Andreini et al. 2008). Metals such as $\mathrm{Fe}, \mathrm{Co}, \mathrm{Ni}, \mathrm{Cu}, \mathrm{Zn}, \mathrm{Mn}$ and $\mathrm{Mg}$ are essential for production of most enzymes in soil (Granger \& Ward 2003, Glass \& Orphan 2012).

In the current study, organic content was determined in different soil samples and the maximum organic content was recorded in both Portsaid and EL-Sharqia soil samples. Fungal isolates from ELSharqia had high ability to produce various enzymes much more than those isolates from Portsaid that had the ability to produce only lipase and esterase. This could be due to the higher content of Mn in Portsaid than EL-Sharqia since it was found that Mn could stimulate lipase and esterase production compared to several other metals (Thota et al. 2012). On the other hand, EL-Sharqia soils had high content of different heavy metal (e.g. $\mathrm{Ni}, \mathrm{Zn}$ and $\mathrm{Fe}$ ) and that could be a possible explanation to the high enzyme activity of the fungal isolates from this site (Tripathya et al. 2014).

Moreover, the high organic content and slightly alkaline $\mathrm{pH}$ that were found in EL-Sharqia soils supposed to decrease the toxicity of the high concentration of heavy metal for the fungal cells. This inhibition role or toxicity of heavy metal could be reduced by many factors such as $\mathrm{pH}$ and organic matter content that affect the bioavailability of metal (Blume \& Brümmer 1991, Yuangen \& Paterson 2001, Yuangen et al. 2004). It has been reported that neutral/alkaline soil could contain high 
concentration of $\mathrm{Mn}, \mathrm{Al}$ or $\mathrm{Pb}$ without any remarkable toxicity to microorganisms; however high toxic impacts on microorganisms could developed much lower concentration of metals in acid soils (Marschner \& Kalbitz 2003, Utgikar et al. 2003).

It is well known that $\mathrm{Cu}$ stimulates the production of laccase enzyme (Bugg et al. 2011). Interestingly, it was found in the present study that laccase enzyme was produced by only one fungal isolate from Saint Katherine soil where zero $\mathrm{Cu}$ was detected. That could be due to either the $\mathrm{Cu}$ content in the soil was lower the detection limit of the atomic absorption method or that the production of the laccase enzyme was depended on $\mathrm{Zn}$ and $\mathrm{Fe}$ atoms and that called white laccase (Gomaa \& Momtaz 2015).

Overall, our findings showed that soil characteristics highly affected the enzymatic activities of the fungal isolates from different locations. This finding was in line with the study of Krishnan et al. (2011), in which the enzymatic activities of fungal isolates from different soil types located in Fildes Peninsula, King George Island and Antarctica were investigated and the results revealed that there was a high correlation between the enzyme production by the isolated fungal taxa and the site and characteristics of the collected soil.

Esterase is known as lipolytic enzyme catalyzing the cleavage and formation of ester bonds (Guo et al. 2016). Esterase mainly catalyzes the hydrolysis of ester bonds of short-chain triglycerides or esters (Liu et al. 2013). Although, esterase gained much attention for their wide range of applications, to date very few esterase have been characterized from fungi, in contrast to the number of esterase which have been characterized from bacteria (Fahmy et al. 2008).

In the present study, all the fungal isolates that had high affinity of esterase production were identified to be M. ruber, M. sanguineus and Monascus sp. that were isolated from Ismailia, Damietta and El-Sharqia, respectively. A few studies were investigated enzymes production by Monascus. For instance, Bridge and Hawksworth (1985) and Cannon et al. (1995) studied the enzyme profile of two Monascus species and the findings from both studies indicated a significant capability of esterase production by Monascus. Moreover, other study by Chen et al. (2011) investigated the optimum conditions of esterase production by M. fulginosus.

Our findings revealed that each Monascus species isolated from each location had a unique affinity of esterase production. Monascus ruber isolated from Ismailia had the maximum esterase activity, while Monascus sp. isolated from EL-Sharqia had the minimum esterase activity. Moreover, the affinity of esterase activity varied by time for each Monascus species. Two main factors, $\mathrm{pH}$ and heavy metals could affect the esterase production by Monascus. Since esterase production is very sensitive to the $\mathrm{pH}$ value, thus it could be a possible explanation of the high esterase activity of $M$. ruber and the low esterase activity of Monascus sp. The $\mathrm{pH}$ of Ismailia soil was 7.75 and of ELSharqia soil was 8.25. Chen et al. (2011) showed that the capability of esterase production by Monascus sp. increased when the $\mathrm{pH}$ value increased. Other studies reported same observation is that optimum conditions for esterase activity by Monascus at $\mathrm{pH}$ values above 7.0 and are stable in a narrow alkaline pH range (Cieslinski et al. 2007, Sumby et al. 2009, Rao et al. 2011). Moreover, Cherif et al. (2011) found that high activity and stability of esterase by Monascus was achieved when $\mathrm{pH}$ values ranged between 7 and 8 .

Heavy metals are the other major factor affecting esterase production. High concentration of metal ions such as $\mathrm{Fe}^{3+}, \mathrm{Cu}^{2+}, \mathrm{Zn}^{2+}, \mathrm{Mn}^{2+}, \mathrm{Co}^{2+}, \mathrm{Ca}^{2+}, \mathrm{Ag}^{+}$could inhibit esterase production (Bannerman et al. 1976). Such inhibitors could alter the catalytic action of the enzyme and consequently slow down, or in some cases, stop catalysis (Degrassi et al. 1998). On the other hand, some metal ions could contribute in maintaining the enzyme in active and stable structure by binding to the amino acid residues with negative charge in specific sites (Faiz et al. 2007). Recently, Guo et al. (2016) showed that different metal ions affect the esterase activity of Monascus. When a $1.0 \mathrm{mM}$ concentration of $\mathrm{Ca}^{2+}, \mathrm{Mn}^{2+}, \mathrm{Fe}^{3+}$ or $\mathrm{Ba}^{2+}$ was presented, the residual esterase activity increased. However, esterase activity was obviously decreased in the presence of $1.0 \mathrm{mM} \mathrm{Cu}{ }^{2+}, \mathrm{Zn}^{2+}$ and $\mathrm{Ag}^{+}$ and was not sensitive to other metal ions such as $\mathrm{Na}^{+}, \mathrm{K}^{+}, \mathrm{Fe}^{2+}, \mathrm{Mg}^{2+}$ and $\mathrm{Co}^{2+}$. Our findings were in agreement with those previous studies since the maximum esterase activity was observed by $M$. ruber isolated from Ismailia and the minimum activity was observed by Monascus sp. isolated from EL- 
Sharqia. That could be due to that the higher concentration of heavy metals ( $\mathrm{Fe}, \mathrm{Zn}, \mathrm{Mn}, \mathrm{Cu}$ and $\mathrm{Ni}$ ) in the soils of EL-Sharqia than Ismailia soils inhibited or decreased the esterase activity.

Polyurethane degradation by fungi has previously been stated to be associated to esterase enzyme activity (Shah et al. 2008). Thus, we have selected the three efficient isolates (M. ruber, M. sanguineus and Monascus sp.) in esterase production for assessing Impranil DLN biodegradation. Monascus sp. isolated from El-Sharqia was the most efficient isolate in degradation of Impranil DLN after 14 days of incubation. To our knowledge, this is the first study that shows the biodegradation of polyurethane (Impranil DLN) by Monascus. However, previous studies investigated the degradation of polyurethane by other fungal genus. For instance, Crabbe et al. (1994) found that four soil fungal species (Curvularia senegalensis, Fusarium solani, Aureobasidium pullulans and Cladosporium sp.) were highly active in degrading polyester polyurethane. Likewise, Russel et al. (2011) found that Pestalotiopsis microspora were able to degrade polyurethane (Impranil DLN) and utilize it as a carbon source. On the other hand, Mathur and Prasad (2012) found that Aspergillus flavus was the more efficient in polyurethane degradation after 30 days of incubation than the other fungal isolates recovered from plastic contaminated soil. Recently, Álvarez-Barragán et al. (2016) showed that the best Impranil degrader was Cladosporium pseudocladosporioides which gave a complete clearance of the Impranil liquid medium after 14 days of incubation.

Interestingly, both SEM micrographs and zeta potential measurements confirmed the adsorption and complex formation between the Impranil DLN and the hyphae of Monascus sp. and that could be the main driver of the high efficiency of this isolate in Impranil DLN degradation. Our finding was in agreement with Blake and Howard (1998) who reported that the pattern of polyurethane degradation involved the binding of microbial cells to the polymer with subsequent floc formation, and then the degradation of substrate. Moreover, Howard (2012) found that the more microbial cells coated with polyurethane, the more polyurethane that was degraded and the more clearance in the liquid medium was observed. Thus, that could be a possible explanation for the high Impranil DLN aggregation on the hyphae of Monascus sp. and the complete clearance in the liquid medium after 14 days.

\section{Conclusion}

Characterization of polymer-degrading soil microorganisms is of major interest for developing novel approaches for biodegradation of plastic wastes in contaminated soils. In the present study, a wide range of enzymes (protease, esterase, lipase, laccase and polyurethanase) were found to be produced by the isolated fungi and these results may demonstrate the important contributions of these isolates in plastic degradation in soil. The activity and concentration of enzymes (especially esterase) produced by the fungal isolates from the different locations strongly suggests that the factors (e.g. $\mathrm{pH}$, organic matter content and heavy metals) have a great effect on the enzyme biosynthesis by fungi. Moreover, Monascus could be considered as one of the best polyurethane biodegraders in soil ecosystem. At present, there is still little available information about the environmental factors inducing the mechanisms of plastic degradation by fungi. Further studies are needed to investigate how the diversity and function of polymer-degrading fungi change by the characteristics of soils from different sampling sites.

\section{Acknowledgment}

We would like to thank Mohamed Arnos (Suez Canal University, Egypt) for providing us with the map. This work was financed by the grants from Albert \& Maria Bergströms Foundation and the Faculty of Science, Stockholm University, Sweden.

\section{References}

Ali MI, Ahmed S, Robson G, Javed I et al. 2014 - Isolation and molecular characterization of polyvinyl chloride. Journal of Basic Microbiology 54, 18-27. 
Allison SD. 2005 - Cheaters, diffusion and nutrients constrain decomposition by microbial enzymes in spatially structured environments. Ecology Letters 8, 626-635.

Allison SD, Vitousek PM. 2004 - Extracellular enzyme activities and carbon chemistry as drivers of tropical plant litter decomposition. Biotropica 36, 285-296.

Al-Maaded M, Madi NK, Kahraman R, Hodzic A, Ozerkan NG. 2012 - An overview of solid waste management and plastic recycling in Qatar. Journal of Polymers and the Environment 20, 186194.

Altschul S, Gish W, Miller W, Myers EW, Lipman DJ. 1990 - Basic local alignment search tool. Journal of Molecular Biology 215, 403-410.

Álvarez-Barragán J, Domínguez-Malfavón L, Vargas-Suárez M, González-Hernández R et al. 2016 - Biodegradative activities of selected environmental fungi on a polyester polyurethane varnish and polyether polyurethane Foams. Applied and Environmental Microbiology 82, 5225-5235.

Anastasi A, Tigini V, Varese GC. 2013 - The bioremediation potential of different ecophysiological groups of fungi. In: Fungi as bioremediator. Soil Biology book series, 32.

Andreini C, Bertini I, Cavallaro G, Holliday GL, Thornton JM. 2008 - Metal ions in biological catalysis: from enzyme databases to general principles. Journal of Biological Inorganic Chemistry 13, 1205-1218.

Bakir ZB, Metin K. 2015 - Screening for industrially important enzymes from thermophilic bacteria; selection of lipase-producing microorganisms and optimization of culture conditions. European Journal of Biotechnology and Bioscience 3, 43-48.

Banerjee S, Bora S, Thrall PH, Richardson AE. 2016 - Soil C and N as causal factors of spatial variation in extracellular enzyme activity across grassland-woodland ecotones. Applied Soil Ecology 105, 1-8.

Bannerman EN, Nicolet J. 1976 - Isolation and characterization of an enzyme with esterase activity from Micropolyspora faeni. Applied and Environmental Microbiology 32, 138-144.

Bhardwaj H, Gupta R, Tiwari A. 2012 - Microbial population associated with plastic degradation. Scientific Reports 5, 272-274.

Blake RC, Howard GT. 1998 - Adhesion and growth of a Bacillus sp. on a polyesterurethane. International Biodeterioration and Biodegradation 42, 63-73.

Blume HP, Brümmer G. 1991 - Prediction of heavy metal behavior in soil by means of simple field tests. Ecotoxicology and Environmental Safety 22, 164-174.

Bowles TM, Acosta-Martínez V, Calderón F, Jackson LE. 2014 - Soil enzyme activities, microbial communities, and carbon and nitrogen availability in organic agroecosystems across an intensively-managed agricultural landscape. Soil Biology and Biochemistry 68, 252-262.

Bradner JR, Gillings M, Nevalainen KMH. 1999 - Qualitative assessment of hydrolytic activities in Antarctic microfungi grown at different temperatures on solid media. World Journal of Microbiology and Biotechnology 15, 131-132.

Bridge PD, Hawksworth DL. 1985 - Biochemical tests as an aid to identification of Monascus species. Letters in Applied Microbiology 1, 25-29.

Broszeit S, Hattam C, Beaumont N. 2016 - Bioremediation of waste under ocean acidification: Reviewing the role of Mytilus edulis. Marine Pollution Bulletin 103, 5-14.

Bugg TD, Ahmad M, Hardiman EM, Singh R. 2011 - The emerging role for bacteria in lignin degradation and bio-product formation. Current Opinion in Biotechnology 22, 394-400.

Cannon PF, Abdullah SK, Abbas BA. 1995 - Two new species of Monascus from Iraq, with a key to known species of the genus. Mycological Research 99, 659-662.

Castro GR, Stettler AO, Ferrero MA, Sifieriz F. 1992 - Selection of an extracellular esteraseproducing microorganism. Journal of Industrial Microbiology 10, 165-168.

Chen M, Liu H, Zhen D, Fang S. 2011 - Research on the esterification property of esterase produced by Monascus sp.. African Journal of Biotechnology 10, 5166-5172.

Cherif S, Mnif S, Hadrich F, Abdelkafi S, Sayadi S. 2011 - A newly high alkaline lipase: an ideal choice for application in detergent formulations. Lipids in health and disease 10, 221-228. 
Christenson EM, Patel S, Anderson JM, Hiltner A. 2006 - Enzymatic degradation of poly(ether urethane) and poly(carbonate urethane) by cholesterol esterase. Biomaterials 27, 3920-3926.

Cieslinski K, Bialkowska AM, Dlugolecka A, Daroch M et al. 2007 - A cold-adapted esterase from psychrotrophic Pseudoalteromas sp. strain 643A. Archives of Microbiology 188, 27-36.

Crabbe JR, Campbell JR, Thompson L, Walz SL, Schultz WW. 1994 - Biodegradation of a colloidal ester-based polyurethane by soil fungi. International Biodeterioration and Biodegradation 33, 103-113.

Das PM, Kumar S. 2014 - Microbial deterioration of low density polyethylene by Aspergillus and Fusarium sp.. International Journal of ChemTech Research 6, 299-305.

Degrassi G, Okeke BC, Bruschi CV, Venturi, V. 1998 - Purification and characterization of an acetyl xylan esterase from Bacillus pumilis. Applied and Environmental Microbiology 64, 789-792.

Doi Y. 1990 - Microbial Polyesters. VCH, New York.

Duncan SM, Minasaki R, Farrell RL, Thwaites JM et al. 2008 - Screening fungi isolated from historic Discovery Hut on Ross Island, Antarctica for cellulose degradation. Antarctic Science 20, 463470.

Echlin P. 2009 - Handbook of sample preparation for scanning electron microscopy and X-ray microanalysis. Springer, New York.

Fahmy AS, Abo-Zeid AZ, Mohamed TM, Ghanem HM et al. 2008 - Characterization of esterases from Cucurbita pepo cv. "Eskandrani". Bioresource technology 99, 437-433.

Faiz Ö, Colak A, Saglam N, Çanakçi S, Beldüz AO. 2007 - Determination and characterization of thermostable esterolytic activity from a novel thermophilic Anoxybacillus gonensis A4. Journal of biochemistry and molecular biology 40, 588-594.

Glass JB, Orphan VJ. 2012 - Trace metal requirements for microbial enzymes involved in the production and consumption of methane and nitrous oxide. Frontiers in Microbiology 3, 61.

Gnanasalomi VDV, Gnanadoss JJ. 2013 - Molecular characterization and phylogenetic analysis of laccase producing fungal isolates with dye decolourizing potential. Research in Biotechnology 4, 01-08.

Gomaa OM, Momtaz OA. 2015 - Copper induction and differential expression of laccase in Aspergillus flavus. Brazilian journal of microbiology 46, 285-292.

Granger J, Ward BB. 2003 - Accumulation of nitrogen oxides in copper-limited cultures of denitrifying bacteria. Limnology and Oceanography 48, 313-318.

Gu JD, Ford TE, Mitton DB, Mitchell R. 2000a - Microbial corrosion of metals. In: Revie W (ed) The Uhlig Corrosion Handbook, 2nd edn. Wiley, New York, pp 915-927.

Gu JD, Ford TE, Mitton DB, Mitchell R. 2000b - Microbial degradation and deterioration of polymeric materials. In: Revie W (ed) The Uhlig Corrosion Handbook, 2nd edn. Wiley, New York, pp 439-460.

Guo H, Zhang Y, Shao Y, Chen W et al. 2016 - Cloning, expression and characterization of a novel cold-active and organic solvent-tolerant esterase from Monascus ruber M7. Extremophiles 20, 451-459.

Halden RU. 2010 - Plastics and Health Risks. Annual Review of Public Health 31, 179-194.

Heiri O, Lotter A, Lemcke G. 2001 - Loss on ignition as a method for estimating organic and carbonate content in sediments: reproducibility and comparability of results. Journal of Paleolimnology 25, 101-110.

Hosoya S, Jang J-H, Yasumoto-Hirose M, Matsuda S, Kasai H. 2009 - Psychromonas agarivorans sp. nov., a novel agarolytic bacterium. International Journal of Systematic and Evolutionary Microbiology 59, 1262-1266.

Howard GT. 2012 - Polyurethane biodegradation. In: Singh S.N. (ed) Microbial degradation of xenobiotics. Springer, Berlin, Heidelberg, pp 371-394.

Huang Q, Shindo H. 2000 - Effects of copper on the activity and kinetics of free and immobilized acid phosphatase. Soil Biology and Biochemistry 32, 1885-1892.

Ibrahim IN, Maraqa A, Hameed KM, Saadoun IM, Maswadeh HM. 2011 - Assessment of potential plastic degrading fungi in Jordanian habitats. Turkish Journal of Biology 35, 551-557. 
Indumathi A, Gayathri T. 2016 - Plastic Degrading ability of Aspergillus oryzae isolated from the garbage dumping sites of Thanjavur, India. International Journal of Current Microbiology and Applied Sciences 3, 8-13.

Jayasekara R, Harding I, Bowater I, Lornergan G. 2005 - Biodegradability of selected range of polymers and polymer blends and standard methods for assessment of biodegradation. Journal of Polymers and the Environment 13, 231-251.

Khan S, Cao Q, Hesham AEL, Xia Y, He J. 2007 - Soil enzymatic activities and microbial community structure with different application rates of $\mathrm{Cd}$ and $\mathrm{Pb}$. Journal of environmental sciences19, 834-840.

Kim DY, Rhee YH. 2003 - Biodegradation of microbial and synthetic polyesters by fungi. Applied microbiology and biotechnology 61, 300-308.

Kordel M, Hofmann B, Schomburg D, Schmid RD. 1991 - Extracellular Lipase of Pseudomonas sp. Strain ATCC 21808: Purification, Characterization, Crystallization, and Preliminary X-Ray Diffraction Data. Journal of Bacteriology 173, 4836-4841.

Krishnan A, Alias SA, Wong CMVL, Pang KL, Convey P. 2011 - Extracellular hydrolase enzyme production by soil fungi from King George Island, Antarctica. Polar Biology 34, 1535-1542.

Lauber CL, Hamady M, Knight R, Fierer N. 2009 - Pyrosequencing-based assessment of soil pH as a predictor of soil bacterial community structure at the continental scale. Applied and Environment Microbiology 75, 5111-5120.

Lipsa R, Tudorachi N, Darie-Nita R N, OpricaL et al. 2016-Biodegradation of poly(lactic acid) and some of its based systems with Trichoderma viride. International Journal of Biological Macromolecules 88, 515-526.

Liu Y, Xu H, Yan Q, Yang S et al. 2013 - Biochemical Characterization of a First Fungal Esterase from Rhizomucor miehei Showing High Efficiency of Ester Synthesis. PLoS ONE 8(10): e77856.

Loredo-Trevino A, Garcia G, Velasco-Tellez A, Rodriguez-Herrera R. 2011 - Polyurethane foam as substrate for fungal strains. Advances in Bioscience and Biotechnology 2, 52-58.

Maeda H, Yamagata Y, Abe K, Hasegawa F et al. 2005 - Purification and characterization of a biodegradable plastic-degrading enzyme from Aspergillus oryzae. Applied microbiology and biotechnology 67, 778-788.

Maiti SK. 2003 - Handbook of methods in environmental studies, vol 2, Air, noise, soil, overburden, solid waste and ecology. ABD Publishers, Japur.

Malý S, Fiala P, Reininger D, Obdržálková E. 2014 - The relationships among microbial parameters and the rate of organic matter mineralization in forest soils, as influenced by forest type. Pedobiologia 57, 235-244.

Marschner B, Kalbitz K. 2003 - Control of bioavailability and biodegradation of dissolved organic matter in soils Geoderma 113, 211-235.

Mathur G, Prasad R. 2012 - Degradation of polyurethane by Aspergillus flavus (ITCC 6051) isolated from Soil. Applied Biochemistry and Biotechnology 167, 1595-160.

Mostafa IMK. 2016 - Promoting recycling in the solid waste management system of Cairo. Master thesis, American University in Cairo.

Muenmee S, Chiemchaisri W, Chiemchaisri C. 2016 - Enhancement of biodegradation of plastic wastes via methane oxidation in semi-aerobic landfill. International Biodeterioration and Biodegradation 113, 244-255.

Nicol GW, Leininger S, Schleper C, Prosser JI. 2008 - The influence of soil pH on the diversity, abundance and transcriptional activity of ammonia oxidizing archaea and bacteria. Environmental microbiology 10, 2966-2978.

North EJ, Halden RU. 2013 - Plastics and Environmental Health: The Road Ahead. Reviews on environmental health $28,1-8$.

Raaman N, Rajitha N, Jayshree A, Jegadeesh R. 2012 - Biodegradation of plastic by Aspergillus spp. isolated from polythene polluted sites around Chennaipage. Journal of Academia and Industrial Research 1, 313-316. 
Rao L, Xue YF, Zhou C, Tao J et al. 2011 - A thermostable esterase from Thermoanaerobacter tengcongensis opening up a new family of bacterial lipolytic enzymes. Biochimica et Biophysica Acta 1814, 1695-1702.

Russell JR, Huang J, Anand P, Kucera K et al. 2011 - Biodegradation of polyester polyurethane by endophytic fungi. Applied and environmental microbiology 77, 6076-6084.

Shah AA, Hasan F, Hameed A, Ahmed S. 2008 - Biological degradation of plastics: A comprehensive review. Biotechnology Advances 26, 246-265.

Shimao M. 2001 - Biodegradation of plastics. Current opinion in biotechnology 12, 242-247.

Sierra G. 1956 - A simple method for the detection of lipolytic activity of microorganisms and some observations on the influence of the contact between cells and fatty substrates. Antonie van Leeuwenhoek 23, 15-22.

Sinsabaugh RL, Lauber CL, Weintraub M, Ahmed B et al. 2008 - Stoichiometry of soil enzyme activity at global scale. Ecology Letters 11, 1252-1264.

Stursova M, Sinsabaugh RL. 2008 - Stabilization of oxidative enzymes in desert soil May limit organic matter accumulation. Soil Biology and Biochemistry 40, 550-553.

Sumathi T, Srilakshmi A, Sai Gopal DVR. 2016 - Isolation of fungi from plastic dumped soils and screening for laccase enzyme activity. World journal of pharmacy and pharmaceutical sciences $5,1591-1596$.

Sumby KM, Matthews AH, Grbin PR, Jiranek V. 2009 - Cloning and characterization of an intracellular esterase from the wine-associated lactic acid bacterium Oenococcus oeni. Applied and Environmental Microbiology 75, 6729-6735.

Thompson RC, Moore CJ, vom Saal FS, Swan SH. 2009 - Plastics, the environment and human health: current consensus and future trends. Philosophical Transactions of the Royal Society B 364, 2153-2166.

Thota P, Bhogavalli PK, Rao VP, Sreerangam V. 2012 - Screening and identification of potential fungal strains for the production of extracellular lipase from soil. Plant science feed 2, 79-84.

Tokiwa Y, Calabia BP, Ugwu CU, Aiba S. 2009 - Biodegradability of plastics. International Journal of Molecular Sciences 10, 3722-3742.

Tripathy S, Bhattacharyya P, Mohapatra R, Som A, Chowdhury D. 2014 - Influence of different fractions of heavy metals on microbial ecophysiological indicators and enzyme activities in century old municipal solid waste amended soil. Ecological Engineering 70, 25-34.

Utgikar VP, Tabak HH, Haines JR, Govind R. 2003 - Quantification of toxic inhibitory impact of copper and zinc on mixed cultures of sulfate reducing bacteria. Biotechnology and Bioengineering 82, 306-312.

Vermelho BA, Meirelles MN, Lopes A, Petinate S et al. 1996 - Detection of extracellular protease from Microorganisms on agar plates. Memórias do Instituto Oswaldo Cruz 91, 755-760.

Wahsha M, Nadimi-Goki M, Fornasier F, Al-Jawasreh R, Hussein EI, Bini C. 2017 - Microbial enzymes as an early warning management tool for monitoring mining site soils. CATENA 148, $40-45$.

Yuangen Y, Congqiang L, Lei X, Pan W, Guoping Z. 2004 - Effects of heavy metal contamination on microbial biomass and community structure in soils. Chinese Journal of Geochemistry 23, 319-328.

Yuangen Y, Paterson E. 2001 - Use of the soil microbial methods to assess the toxicity of the heavy metal $\mathrm{Cu}$ and its time effects. Progress in Natural Science: Materials International 11, 243-249.

Zafar U, Nzeram P, Langarica-Fuentes A, Houlden A et al. 2014 - Biodegradation of polyester polyurethane during commercial composting and analysis of associated fungal communities. Bioresource Technology 158, 374-377.

Zahra S, Abbas S, Taheri Mahsa M, Mohsen N. 2010 - Biodegradation of low-density polyethylene (LDPE) by isolated fungi in solid waste medium. Waste Management 30, 396-401.

Zhang C, Morac P, Daia J, Chena X et al. 2016 - Earthworm and organic amendment effects on microbial activities and metal availability in a contaminated soil from China. Applied Soil Ecology 104, 54-66. 